Priambodo, et al/Jurnal Ekonomi Syariah Teori dan Terapan Vol. 6 No. 10 Oktober 2019: 2062-2076; PENGARUH BANK SYARIAH YANG DIKELOLA BERDASARKAN PRINSIP SYARIAH SERTA FITUR DAN FASILITAS PRODUK PERBANKAN SYARIAH TERHADAP MINAT MENABUNG MASYARAKAT DI SURABAYA

\title{
PENGARUH BANK SYARIAH YANG DIKELOLA BERDASARKAN PRINSIP SYARIAH SERTA FITUR DAN FASILITAS PRODUK PERBANKAN SYARIAH TERHADAP MINAT MENABUNG MASYARAKAT DI SURABAYA
}

\author{
Bobby Raditya Priambodo \\ Departemen Ekonomi Syariah-Fakultas Ekonomi dan Bisnis-Universitas Airlangga \\ Email: brpriambodo-12@feb.unair.ac.id \\ Dina Fitrisia Septiarini \\ Departemen Ekonomi Syariah-Fakultas Ekonomi dan Bisnis-Universitas Airlangga \\ Email: dina.fitrisia@feb.unair.ac.id
}

\begin{abstract}
:
This study aims to determine the Effect of Compliance with Sharia Compliance Management and Sharia Banking Product Features and Facilities Against the Interests of Surabaya People in Saving in Islamic Banking. The research method used is a quantitative approach. This study uses primary data by distributing questionnaires. In this study the authors used a saturated sampling technique found in Non-Probability Sampling. The analysis techniques used are validity and reliability tests, classic assumption tests, hypothesis tests. Based on the results of the study indicate that there is a one-way relationship on several variables, namely sharia compliance and product features and facilities to save interest.

Keywords: Sharia Complience, Sharia Banking Product Facilities, Sharia Banks.
\end{abstract}

\section{PENDAHULUAN}

Negara Indonesia merupakan negara dengan mayoritas penduduk beragama Islam, seiring berjalanan nya waktu literasi keuangan dengan berbasis dasar ilmu dan hukum Islam tentu nya juga berkembang di Indonesia. Perbankan sendiri merupakan lembaga keuangan yang memiliki peranan keuangan yang cukup penting bagi masyarakat Indonesia. Sejarah munculnya bank syariah di Indonesia sendiri didirikan pada tahun 1992 yang bernama Bank Muamalat Indonesia, tetapi menurut Rivai dan Arifin, (2010:131) Bank Syariah Indonesia baru disahkan oleh pemerintah Indonesia pada tahun 1998. Bank syariah sendiri menurut Undang-Undang Perbankan No. 10 tahun 1998 UU No. 10
Tahun 1998 tentang perubahan UU No. 7 Tahun 1992 berarti bahwa bank syariah merupakan bank umum yang melaksanakan kegiatan usahanya berdasarkan prinsip Islam yang dalam menjalankan kegiatannya.

$$
\text { Menurut Ningsih (2012) dalam }
$$

Arianto (2016) konsep ekonomi syariah pada bidang perbankan diyakini dapat menjadi sistem yang efektif dan tidak memiliki pengaruh terhadap gejolak krisis ekonomi seperti pada tahun 1998. Pada tanggal 16 Desember 2003 Komisi Fatwa Majelis Ulama Indonesia juga sudah mengambil langkah untuk memutuskan bahwa bunga bank adalah riba dan riba sendiri hukumnya haram. Prinsip perbankan syariah ini sebenarnya dirasa cukup mengguntungkan untuk

\footnotetext{
${ }^{1}$ Jurnal ini merupakan bagian dari skripsi dari Bobby Raditya Priambodo, NIM: 041211431004 , yang diuji pada tanggal 16 Juli 2019.
} 
Priambodo, et al/Jurnal Ekonomi Syariah Teori dan Terapan Vol. 6 No. 10 Oktober 2019: 2062-2076; PENGARUH BANK SYARIAH YANG DIKELOLA BERDASARKAN PRINSIP SYARIAH SERTA FITUR DAN FASILITAS PRODUK PERBANKAN SYARIAH TERHADAP MINAT MENABUNG MASYARAKAT DI SURABAYA

masyarakat Indonesia pada umum nya sebagai nasabah, hal tersebut juga didukung oleh aturan dalam agama islam yang melarang adanya bunga atau riba sebagai pendapatan bagi umat muslim sebagaimana tertera dalam surat AlBaqarah ayat 275 , sebagai berikut.

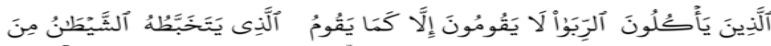

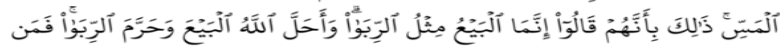

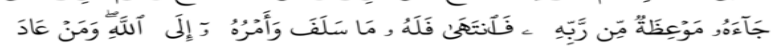

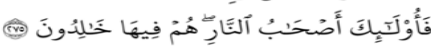

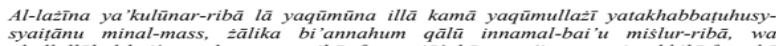

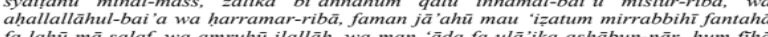
fa lahü $m$ mith
khälidün

Artinya: Orang-orang yang memakan riba tidak dapat berdiri melainkan seperti berdirinya orang yang kemasukan setan karena gila. Yang demikian itu karena mereka berkata bahwa jual beli itu sama dengan riba. Padaha Allah telah menghalalkan jual beli dan mengharamkan riba. Barangsiapa mendapat peringatan dari Tuhannya, lalu dia berhenti, maka apa yang telah diperolehnya dahulu menjadi miliknya dan urusannya (terserah) kepada Allah. Barangsiapa mengulangi, maka mereka itu penghuni neraka, mereka kekal di dalamnya. (Departemen Agama Replubik Indonesia, 2015)

Dalam industri perbankan sendiri dikenal dengan istilah syariah compliance atau kepatuhan yang berdasarkan dengan aturan yang mengikat institusi perbankan itu sendiri. Di Indonesia bank Indonesia ditunjuk dan memiliki otoritas untuk mengatur regulator perbankan di Indonesia yang memberikan standar nasional tentang perbankan kepada seluruh pelaku perbankan di Indonesia.
Bank Indonesia sendiri telah mengeluarkan berbagai ketentuan mengenai pengendalian internal bank dan sistem pengendalian tersebut berupa kebijakan, prosesur kerja yang berfungsi sebagai check and balance. Menurut Mulazid (2016) salah satu pilar yang menjadi pembeda adalah syariah compliance, sehingga perlu adanya pengawasan syariah yang diperankan oleh Dewan Pengawas Syariah (DPS). Lembaga perbankan syariah selain diawasi langsung oleh dua dewan penggawas, juga memiliki beberapa fasilitas yang membuat nasabahnya lebih diuntungkan apabila dibandingkan dengan bank konvensional. Selain fasilitas yang didapatkan sama seperti ketersediaan mesin ATM, kantor cabang yang sudah terbuka di seluruh wilayah Indonesia dan tidak adanya biaya admin yang dibebankan kepada nasabah. Lembaga perbankan syariah juga tidak menerapkan sistem bunga atau riba dalam kegiatan usahanya.

Berdasarkan data dari Otoritas Jasa Keuangan pada tahun 2019 jumlah kantor cabang, kantor cabang pembantu dan kantor kas lembaga perbank syariah di Jawa Timur menempati angka 200 kantor yang tersebar di seluruh wilayah Jawa Timur. Di kota Surabaya sendiri penduduk beragama islam mendominasi dan menduduki peringkat pertama. Pada tahun 2016 berdasarkan data dari Badan Pusat Statistik Provinsi Jawa Timur dapat diketahui bahwa jumlah penduduk muslim 
Priambodo, et al/Jurnal Ekonomi Syariah Teori dan Terapan Vol. 6 No. 10 Oktober 2019: 2062-2076; PENGARUH BANK SYARIAH YANG DIKELOLA BERDASARKAN PRINSIP SYARIAH SERTA FITUR DAN FASILITAS PRODUK PERBANKAN SYARIAH TERHADAP MINAT MENABUNG MASYARAKAT DI SURABAYA

kota Surabaya sebanyak 2.449.116. Berdasarkan data tersebut dapat dilihat jumlah pemeluk agama islam di Jawa Timur dan Surabaya menduduki jumlah pemeluk agama mayoritas, sehingga hal tersebut dapat dijadikan acuan oleh lembaga perbankan syariah cabang Surabaya untuk mendapatkan nasabah. Dalam penelitian ini, peneliti ingin melihat respon dari masyarakat Surabaya mengenai syariah compliance dan fasilitas yang dimiliki oleh lembaga perbankan syariah di Surabaya terhadap minat masyarakat dalam membuat menabung di lembaga perbankan syariah.

\section{II. PENGEMBANGAN HIPOTESIS}

LANDASAN TEORI DAN

\section{Perbankan Syariah}

Menurut Bank Indonesia (2005)

Bank Syariah merupakan lembaga perbankan yang melaksanakan kegiatan usaha berdasarkan prinsip syariah atau prinsip ekonomi Islam, yaitu aturan perjanjian berdasarkan prinsip hukum Islam antara bank dan pihak - pihak lain diluar bank dengan tujuan untuk menyimpan dana dan atau pembiayaan kegiatan usaha yang sesuai dengan prinsip syariah. Bank syariah pun juga mempunyai fungsi yang berbeda dengan bank konvesional lainnya. Menurut Andespa (2016) terdapat 3 fungsi operasional dalam bank syariah sebagai berikut.

1. Penghimpunan dana pada bank syariah memiliki fungsi utama pihak penabung tidak mendapatkan balas jasa berupa bunga, tetapi dalam bank syariah penabung akan mendapatkan balas jasa berupa bagi hasil.

2. Penyalur dana, fungsi utama bank syariah yang kedua adalah sebagai penyalur dana. Dana yang telah dihimpun dari nasabah, nantinya akan disalurkan kembali kepada nasabah lainnya dengan sistem bagi hasil.

3. Memberikan pelayanan jasa bank, fungsi bank syariah yang ketiga adalah sebagai pemberi layanan jasa perbankan. Dalam hal ini bank syariah berfungsi sebagai pemberi layanan jasa seperti jasa transfer, pemindah bukuan, jasa tarikan tunai, dan jasajasa perbankan lainnya.

\section{Shariah Compliance}

Menurut Otoritas Pengawas Syariah (2009) dalam Mulazid (2016) kepatuhan syariah merupakan fungsi utama dari integritas dan kredibilitas lembaga perbankan syariah. Eksistensi bank syariah ditentukan oleh apakah lembaga perbankan syariah tersebut dapat memenuhi kebutuhan masyarakat muslim akan pelaksanaan ajaran Islam secara menyuluruh (kaffah) termasuk didalamnya merupakan kegiatan penyaluran dana melalui bank syariah. Kepercayaan masyarakat akan lembaga perbankan syariah akan didasari pada pelaksanaanya yang apakah murni menggunakan prinsip hukum islam tanpa adanya pengecualian-pengecualian lainnya. Kepatuhan syariah atau Syariah 
Priambodo, et al/Jurnal Ekonomi Syariah Teori dan Terapan Vol. 6 No. 10 Oktober 2019: 2062-2076; PENGARUH BANK SYARIAH YANG DIKELOLA BERDASARKAN PRINSIP SYARIAH SERTA FITUR DAN FASILITAS PRODUK PERBANKAN SYARIAH TERHADAP MINAT MENABUNG MASYARAKAT DI SURABAYA

Compliance memiliki standar internasional yang disusun dan ditetapkan oleh Islamic Financial Service Board (IFSB) yang di mana kepatuhan syariah merupakan bagian dari tata kelola lembaga atau corporate governance. Kepatuhan syariah tersebut secara konsisten dijadikan sebagai kerangka kerja bagi sistem dan kevangan bank syariah dalam alokasi sumber daya, manajemen, produksi, aktivitas pasar modal dan distribusi kekayaan.

\section{Indikator Shariah Compliance}

Berdasarkan Peraturan Bank Indonesia Nomor 13/2/PBI/2011 tentang Pelaksanaan Fungsi Kepatuhan Bank Umum, maka yang dimaksud kepatuhan adalah nilai, perilaku, dan tindakanyang mendukung terciptanya kepatuhan terhadap ketentuan Bank Indonesia dan peraturan perundang-undangan yang berlaku, termasuk prinsip syariah bagi bank umum syari'ah dan unit usaha syari'ah (Peratuaran Bank Indonesia Nomor 13/2/PBI/2011 tentang Pelaksanaan Fungsi Kepatuhan Bank Umum). Menurut afridawati (2017) Kepatuhan syariah (shariah compliance) adalah syarat mutlak yang harus dipatuhi dan dijalankan oleh lembaga perbankan syariah yang menjalankan kegiatan usaha berdasarkan prinsip syariah khususnya bank syariah.

Indikator Tidak Ada Riba Dalam Transaksi Bank

Dalam indikator ini setiap transaksi sewa menyewa dana maupun menabung di dalam lembaga perbankan syariah pihak yang melakukan tersebut tidak akan mendapatkan keuntungan dalam bentuk bunga atau riba. Beberapa dalil yang menunjukkan hukum riba itu haram ialah ayat Al-Qur'an surat Ar-Ruum: 39, diturunkan di Mekah, menegaskan bahwa bunga akan men- jauhkan keberkahan Allah dalam kekayaan, sedangkan sedekah akan meningkatkannya terlipat ganda dan surat An-Nisaa': 161, diturunkan pada masa permulaan periode Madinah, mengutuk dengan keras praktek riba, seirama dengan larangannya pada kitabkitab terdahulu.

\section{Indikator Tidak Ada Gharar Dalam Transaksi Bank}

Dalam indikator ini gharar memiliki arti keraguan, tipuan atau tindakan yang bertujuan untuk merugikan pihak lain. Dalam indikator ini lembaga perbankan syariah tidak boleh menggunakan suatu akad yang mengandung unsur penipuan, karena tidak ada kepastian, baik mengenai ada atau tidak ada objek akad, besar kecil jumlah maupun menyerahkan objek akad tersebut. Imam Al-Qarafi (Hasan, 2010 dalam Afridawti, 2017) menjelaskan bahwa gharar merupakan suatu akad yang diketahui dengan tegas, apakah efek akad akan terlaksana atau tidak, seperti melakukan jual beli ikan yang masih di dalam air.

Indikator Tidak Ada Maysir Dalam Transaksi Bank. 
Priambodo, et al/Jurnal Ekonomi Syariah Teori dan Terapan Vol. 6 No. 10 Oktober 2019: 2062-2076; PENGARUH BANK SYARIAH YANG DIKELOLA BERDASARKAN PRINSIP SYARIAH SERTA FITUR DAN FASILITAS PRODUK PERBANKAN SYARIAH TERHADAP MINAT MENABUNG MASYARAKAT DI SURABAYA

Dalam indikator ini maysir berarti qimar atau judi. Maysir dalam definisi nya merupakan suatu transaksi yang digantungkan kepada suatu keadaan yang tidak pasti dan bersifat mengadu nasib atau untung-untungan. Secara sederhana, maysir atau perjudian adalah suatu permainan yang menjadikan salah satu pihak menanggung beban pihak lain akibat permainan tersebut. Menurut Karim (2007) dalam Afridawti (2017) keadaan yang menjadikan salah satu pihak harus menanggung beban pihak yang lain merupakan definisi dari maysir.

\section{Dewan Pengawas Syariah}

Menurut Budiono (2017) Lembaga perbankan syariah dalam melakukan kegiatan operasionalnya harus berasaskan pada prinsip syariah, demokrasi ekonomi, dan prinsip kehati hatian. Prinsip syariah atau shariah complianc merupaka prinsip hukum Islam dalam kegiatan perbankan berdasarkan fatwa yang dikeluarkan oleh Majelis Ulama Indonesia.

\section{Dewan Syariah Nasional}

Dewan syariah nasional merupakan lembaga non-pemerintah yang didirikan oleh Majelis Ulama Indonesia (MUI) yang bertugas untuk mengkaji, menggali serta merumuskan nilai-nilai dan prinsip hukum islam dalam bentuk fatwa yang nantinya wajin dijadikan pedoman dalam kegiatan transaksi di lembaga perbankan syariah.

\section{Produk Lembaga Perbankan Syariah}

Berikut merupakan jenis produk dari lembaga perbankan syariah menurut Andespa (2016).

1. Produk Simpanan Murni (al-Wadiah

Fasilitas simpanan murni merupakan fasilitas yang diberikan lembaga perbankan syariah untuk memberikan kesempatan kepada pihak yang memiliki kelebihan dana untuk menyimpan dananya dalam bentuk alWadiah. Fasilitas al-Wadiah diberikan utnuk tujuan investasi guna mendapatkan keuntungan seperti halnya tabungan dan deposito.

2. Produk Bagi Hasil (Syirkah)

Fasilitas bagi hasil merupakan sistem yang meliputi tata cara pembagian hasil usaha antara penyedia dana dengan lembaga perbankan syariah. Pembagian hasil usaha ini dapat terjadi antara bank dengan penyimpan dana, maupun antara bank dengan nasabah penerima dana.

3. Produk Jual Beli (at-Tijarah)

Fasilitas ini merupakan suatu sistem yang menerapkan tata cara jual beli, dimana lembaga perbankan syariah akan membeli terlebih dahulu barang yang dibutuhkan atau mengangkat nasabah sebagai agen bank melakukan pembelian atas nama bank, kemudian bank menjual barang tersebut kepada nasabah dengan harga beli ditambah keuntungan (margin).

4. Produk Sewa (al-ijarah) 
Priambodo, et al/Jurnal Ekonomi Syariah Teori dan Terapan Vol. 6 No. 10 Oktober 2019: 2062-2076; PENGARUH BANK SYARIAH YANG DIKELOLA BERDASARKAN PRINSIP SYARIAH SERTA FITUR DAN FASILITAS PRODUK PERBANKAN SYARIAH TERHADAP MINAT MENABUNG MASYARAKAT DI SURABAYA

Fasilitas ini secara garis besar terbagi menjadi dua jenis yang pertama merupakan ljarah, sewa murni, hal tersebut seperti halnya penyewaan alat-alat produk (operating lease). Dalam teknis perbankan, bank dapat membeli equipment yang dibutuhkan nasabah kemudian menyewakan dalam waktu dan hanya telah disepakati kepada nasabah. dan yang terakhir merupakan Bai al takjiri atau ijarah al muntahiya bit tamlik merupakan penggabungan sewa dan beli, dimana si penyewa mempunyai hak untuk memiliki barang pada akhir masa sewa (financial lease).

\section{Fasilitas Lembaga Perbankan Syariah}

Dalam bahasan ini fasilitas lembaga perbankan syariah lebih mengarah pada pemasaran fisik langsung yang diberikan kepada nasabah yaitu:

1. Ketersediaan mesin atm (Anjungan Tunai Mandiri, mesin yang melayani nasabah bank untuk mengambil uang dan mengecek rekening tabungan mereka tanpa perlu dilayani oleh teller).

2. Kantor cabang yang mudah ditemui (Kantor bank yang secara langsung bertanggung jawab kepada kantor pusat bank yang bersangkutan dan bertanggung jawab di area yang sudah ditentukan).

3. Ketersediaan internet banking (Layanan melakukan transaksi perbankan melalui jaringan internet).
4. Bebas biaya administrasi bulanan (Biaya yang dibebankan secara berkala kepada pemegang rekening pada suatu bank).

\section{Minat Menabung}

Marilus (2016) langkah-langkah yang diambil seorang calon nasabah yang akan menabung dapat dilihat dari 4 aspek yang akan dijelaskan sebagai berikut:

1. Pengenalan Masalah : Kebutuhan biasanya muncul berdasarkan kebutuhan ataupun gaya hidup yang dimiliki calon nasabah tersebut.

2. Pencarian Informasi : Hal ini mencakup pencarian informasi yang dilakukan oleh calon nasabah.

3. Evaluasi Informasi : Konsumen akan melakukan evaluasi akan produk yang sudah mereka cari informasinya.

4. Keputasan Menabung : Ketika sudah melakukan evaluasi, calon nasabah akan memilih untuk membeli atau menggunakan produk perbankan yang sudah disetujui.

\section{Hipotesis}

$\mathrm{H1}$ : Kepatuhan pengelolaan bank syariah berdasarkan Shariah Compliance berpegaruh terhadap minat masyarakat Surabaya menabung di Lembaga perbankan syariah

H2: Fitur dan fasilitas produk lembaga perbankan syariah berpengaruh terhadap minat masyarakat Surabaya menabung di lembaga perbankan syariah? 
Priambodo, et al/Jurnal Ekonomi Syariah Teori dan Terapan Vol. 6 No. 10 Oktober 2019: 2062-2076; PENGARUH BANK SYARIAH YANG DIKELOLA BERDASARKAN PRINSIP SYARIAH SERTA FITUR DAN FASILITAS PRODUK PERBANKAN SYARIAH TERHADAP MINAT MENABUNG MASYARAKAT DI SURABAYA

H3: Kepatuhan pengelolaan bank syariah berdasarkan Shariah Compliance serta fitur dan fasilitas produk lembaga perbankan syariah berpengaruh terhadap minat masyarakat Surabaya menabung di lembaga perbankan Syariah.

\section{Modal Analisis}

Penelitian ini bertujuan untuk mengetahui kepatuhan pengelolaan bank syariah berdasarkan Shariah Compliance serta fitur dan fasilitas produk lembaga perbankan syariah terhadap minat masyarakat Surabaya menabung di lembaga perbankan syariah dengan menggunakan regresi linear berganda.

$$
Y=a+\beta 1 X 1+\beta 2 X 2+\varepsilon
$$

Keterangan:

$$
\begin{array}{ll}
\mathrm{Y} & =\text { Variabel minat menabung } \\
\mathrm{X} 1 & =\text { Variabel syariah compliance } \\
\mathrm{X} 2 & =\text { Variabel fasilitas lembaga syariah } \\
\mathrm{a} & =\text { konstanta } \\
\beta 1 \beta 2 & =\text { Koefisien regresi } \\
\varepsilon & =\text { Standar Error } \\
& \text { Seluruh variabel yang digunakan }
\end{array}
$$
dalam penelitian ini apabila digambar dalam sebuah model analisis dapat terlihat sebagai berikut:

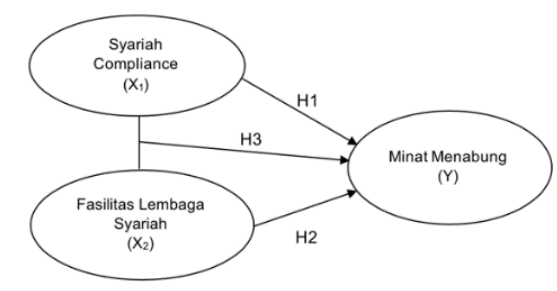

\section{Gambar 1.}

\section{Model Analisis}

\section{METODE PENELITIAN}

\section{Pendekatan Penelitian}

Penelitian ini adalah penelitian dengan menggunakan metode kuantitatif karena menggunakan hipotesis dan disertai dengan pengujian statistik. Pendekatan kuantitatif menurut Suryani dan Hendryadi (2015) merupakan penelitian yang menggunakan data, karena dengan kuantitatif, kita dapat memperoleh data yang berbentuk angka dengan skala rasio.Berdasarkan rumusan masalah dan hipotesis yang digunakan dalam penelitian ini, maka variabel yang dianalisis dalam penelitian ini terdiri dari dua macam variabel yaitu :

1.Variabel Bebas (Variabel X)

Variabel bebas adalah suatu variabel yang dapat berdiri sendiri tanpa pengaruh dari variabel lain dan dianggap sebagai penyebab terjadinya suatu keadaan dalam proses mempengaruhi. Variabel bebas yang digunakan dalam penelitian ini adalah syariah compliance dan fasilitas lembaga syariah.

2. Variabel Terikat (Variabel Y)

Variabel terikat adalah suatu variabel yang tidak dapat berdiri sendiri tanpa pengaruh dari variabel lain, sehingga keberadaan variabel terikat membutuhkan pengaruh dari variabel lain. Variabel terikat yang digunakan dalam penelitian ini adalah minat menabung.

\section{Sampel dan Populasi}

Menurut Sugiyono (2015) populasi adalah merupakan subjek/objek yang berada di wilayah generalisasi yang 
Priambodo, et al/Jurnal Ekonomi Syariah Teori dan Terapan Vol. 6 No. 10 Oktober 2019: 2062-2076; PENGARUH BANK SYARIAH YANG DIKELOLA BERDASARKAN PRINSIP SYARIAH SERTA FITUR DAN FASILITAS PRODUK PERBANKAN SYARIAH TERHADAP MINAT MENABUNG MASYARAKAT DI SURABAYA

mempunyai karakteristik tertentu yang ditetapkan oleh penulis atau peneliti. Populasi yang digunakan dalam penelitian ini adalah masyarakat yang ada dan tinggal di Surabaya sehingga jumlah populasi tidak bisa diidentifikasi. Menurut Sugiyono (2015) purposive sampling yaitu pengambilan anggota sampel diambil dengan memperhatikan syarat-syarat tertentu yang ada dalam populasi tersebut. Dalam penelitian ini, sampel yang akan diambil akan diambil dengan ketentuan usia minimal 17 tahun atau sudah menikah karena kedua syarat tersebut menunjukkan sebagai syarat untuk memiliki KTP, serta ketentuan lain yang digunakan adalah memeluk Agama Islam karena yang diteliti adalah lembaga perbankan syariah, maka sampel yang digunakan pun harus mengerti mengenai syariah.Jumlah masyarakat yang ada ataupun tinggal di Surabaya sangatlah banyak, maka tidak mungkin meneliti semua karena banyak keterbatasan, maka akan ada penentuan sampel. Jumlah sampel yang diteliti ditentukan dengan teori dari Hair et al (2014) yaitu jumlah sampel minimal adalah 5 hingga 10 kali dari jumlah indikator, dan juga ukuran sampel yang sesuai berkisar antara 100-200 responden. Jumlah indikator yang ada pada penelitian ini adalah sebagai berikut :

Indikator $\mathrm{X} 1 \quad: 3$

Indikator $\mathrm{X} 2 \quad: 4$

Indikator $Y: 4$
Maka dengan demikian, penulis mengalikan jumlah total indikator 11 dikalikan dengan 10 maka jumlah sampel total adalah 110

\section{Teknik Pengumpulan Data}

Menurut Ghozali (2016). Kuesioner adalah teknik mengumpulkan data dengn menggunakan pernyataanpernyataan mengenai indikator variabel yang digunakan dalam penelitian. Jenis kuesioner yang digunakan adalah tertutup yang mana jawaban sudah disediakan dengan skala likert, yaitu skala yang berisi pernyataan sistematis untuk menunjukkan sikap responden terhadap indikator. Nilai yang digunakan dalam skala likert pada penelitian ini adalah sebagai berikut :

Tabel 1.

Tabel skala Likert

\begin{tabular}{|c|l|}
\hline Nilai & \multicolumn{1}{|c|}{ Keterangan } \\
\hline 1 & Sangat Tidak Setuju (STS) \\
\hline 2 & Tidak Setuju (TS) \\
\hline 3 & Netral (N) \\
\hline 4 & Setuju (S) \\
\hline 5 & Sangat Setuju (SS) \\
\hline
\end{tabular}

Sumber : Data diolah penulis (2019)

Validitas dan Realibilitas

Menurut Sugiyono (2015) hasil penelitian yang valid bila terdapat kesamaan antara data yang sesungguhnya terjadi pada obyek yang diteliti. Data disebut valid berarti data yang diperoleh melalui kuesioner dapat menjawab tujuan dari penelitian. Untuk mengukur validitas digunakan korelasi pearson product moment. Jika koreasi 
Priambodo, et al/Jurnal Ekonomi Syariah Teori dan Terapan Vol. 6 No. 10 Oktober 2019: 2062-2076; PENGARUH BANK SYARIAH YANG DIKELOLA BERDASARKAN PRINSIP SYARIAH SERTA FITUR DAN FASILITAS PRODUK PERBANKAN SYARIAH TERHADAP MINAT MENABUNG MASYARAKAT DI SURABAYA

pearson product moment antara masing masing pernyataan dengan skor total menghasilkan nilai signifikansi $<0,05$ $(a=5 \%)$, maka item pernyataan dinyatakan valid. Reliabilitas atau reliable Menurut Ghozali (2016) pengukuran reliabilitas dilakukan dengan cara one shot atau pengukuran sekali saja dengan SPSS uji statistik koefisien cronbach alpha dengan syaratr dikatakan reliable jika nilai cronbach alpha adalah $>0,60$.

\section{Uji Normalitas}

Menurut Sugiyono (2017), Uji normalitas untuk menguji apakah nilai residual yang dihasilkan dari regresi terdistribusi secara normal atau tidak. Metode yang digunakan adalah metode grafik, yaitu dengan melihat penyebaran data pada sumber diagonal pada grafik Normal P-P

\section{Uji Multikolinieritas}

Menurut Supriyono et al (2016), suatu model regresi sebaiknya tidak terjadi korelasi di antara variabel independen. Jika variabel independen saling berkorelasi, maka variabel-variabel ini tidak orthogonal.

\section{Uji Linieritas}

Menurut Sugiyono (2017) Uji lineritas ini bertujuan umtuk mengetahui apakah dua variabel mempunyai hubungan yang linear atau tidak secara signifikan. Untuk melakukan uji lineritas, dapat menggunakan test of linearity. Kriteria yang berlaku, jika nilai sig, pada linearity $\leq$ 0,05 ,

\section{Uji Heteroskedastisitas}

Menurut Ghozali (2016) adalah varian residual yang tidak sama pada semua pengamatan didalam model regresi. Regresi yang baik seharusnya tidak terjadi heterokedastitas.

\section{Uji Autokorelasi}

Uji Autokorelasi adalah untuk mengetahui adanya korelasi antara variabel sehingga penaksir tidak lagi efisien baik dalam model sampel kecil maupun dalam sampel besar (Ghozali, 2016). Salah satu cara untuk menguji autokorelasi adalah dengan percobaan d (Durbin-Watson) dengan syarat:

a. $d>4-d L$ maka terjadi autokorelasi negative.

b. $d U<d<4-d U$ maka tidak terjadi autokorelasi.

c. $\mathrm{dL} \leq \mathrm{d} \leq \mathrm{dU}$ maka pengujian tidak meyakinkan.

\section{Analisis Regresi Linear Berganda}

Menurut Widarjono (2014) Analisis regresi linear berganda berfungsi untuk mengetahui seberapa besar arah pengaruh antara variabel bebas (syariah compliance dan faslitias lembaga syariah) terhadap variabel terikat (minat menabung). Perhitungan regresi linear berganda dihitung sebagai berikut, yaitu :

$$
Y=a+\beta 1 X 1+\beta 2 X 2+\varepsilon
$$

Keterangan:

$\mathrm{Y} \quad=$ Variabel minat menabung

$\mathrm{X}_{1}=$ Variabel syariah compliance

X2 = Variabel fasilitas lembaga syariah

a =konstanta

$\beta 1 \beta 2=$ Koefisien regresi

$\varepsilon \quad=$ Standar Error 
Priambodo, et al/Jurnal Ekonomi Syariah Teori dan Terapan Vol. 6 No. 10 Oktober 2019: 2062-2076; PENGARUH BANK SYARIAH YANG DIKELOLA BERDASARKAN PRINSIP SYARIAH SERTA FITUR DAN FASILITAS PRODUK PERBANKAN SYARIAH TERHADAP MINAT MENABUNG MASYARAKAT DI SURABAYA

Uji Signifikansi Simultan (Uji F)

Menurut Suryani dan Hendryadi (2015), Uji F digunakan untuk mengetahui pengaruh variabel bebas secara simultan terhadap variabel terikat. Dengan dasar pengambilan keputusan menggunakan angka probabilitas signifikansi, yaitu:

a. Apabila probabilitas signifikansi < 0,05 maka variabel independen berpengaruh secara bersama-sama.

b. Apabila probabilitas signifikansi $>0,05$ maka variabel independen tidak berpengaruh seacara bersama-sama

Uji Signifikansi Parsial (Uji t)

Menurut Suryani dan Hendryadi (2015), Uji t digunakan untuk menguji secara parsial masing-masing variabel. Dengan dasar pengambilan keputusan menggunakan angka probabilitas signifikansi, yaitu:

a. Apabila probabilitas signifikansi $<0,05$ maka Ho ditolak dan Ha diterima.

b. Apabila probabilitas signifikansi $>0,05$ maka Ho diterima dan Ha ditolak.

\section{HASIL DAN PEMBAHASAN}

Dari hasil pengumpulan data kuesioner pada Tabel 4.10, diketahui bahwa nilai rata-rata pada variabel X1 (Syariah Compliance) adalah 3,636 yang memiliki arti bahwa responden setuju dengan indikator pada variabel Syariah Compliance. Perolehan nilai standar deviasi tertinggi ada pada pernyataan pertama yaitu "Bank syariah tidak memberikan janji nominal tetap imbalan/pendapatan masa depan yang akan didapat nasabah (riba)" sebesar
1.01712 yang berarti jawaban responden lebih beragam, sedangkan nilai standar deviasi terendah pada pada pernyataan kelima yaitu "Semua kegiatan perbankan bank syariah diawasi oleh Dewan Syariah Nasional" sebesar 0.79825 yang artinya jawaban responden cenderung lebih konsisten. Sedangkan perolehan nilai mean tertinggi ada pada pertanyaan pertama yaitu "Bank syariah tidak memberikan janji nominal tetap imbalan/pendapatan masa depan yang akan didapat nasabah (riba)" sebesar 3.7818 yang mana artinya bahwa responden memiliki kecenderungan untuk setuju pada pernyataan ini dibandingkan dengan pernyataan lainnya.

Tabel 2.

\section{Deskripsi Variabel Syariah Compliance}

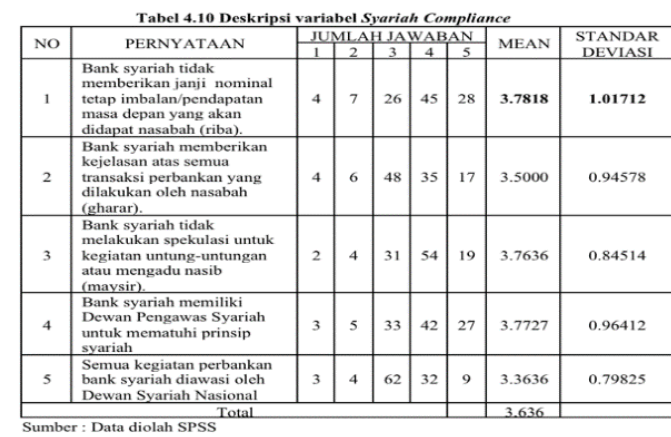

Dari hasil pengumpulan data kuesioner pada Tabel 3, diketahui bahwa nilai rata-rata pada variabel X2 (Fasilitas Lembaga Syariah) adalah 3,782 yang memiliki arti bahwa responden setuju dengan indikator pada variabel Fasilitas Lembaga Syariah. Perolehan nilai standar deviasi tertinggi ada pada pertanyaan pertama yaitu "Cabang bank syariah tersebar merata di Surabaya dan akses mudah dijangkau" sebesar 0,94996 yang 
Priambodo, et al/Jurnal Ekonomi Syariah Teori dan Terapan Vol. 6 No. 10 Oktober 2019: 2062-2076; PENGARUH BANK SYARIAH YANG DIKELOLA BERDASARKAN PRINSIP SYARIAH SERTA FITUR DAN FASILITAS PRODUK PERBANKAN SYARIAH TERHADAP MINAT MENABUNG MASYARAKAT DI SURABAYA

berarti jawaban responden lebih beragam, sedangkan nilai standar deviasi terendah pada pada pernyataan keempat yaitu "Nasabah mendapat kemudahan dalam melakukan transaksi bank melalui internet/mobile banking" sebesar 0.74356 yang artinya jawaban responden cenderung lebih konsisten. Sedangkan perolehan nilai mean tertinggi ada pada pertanyaan keempat yaitu "Nasabah mendapat kemudahan dalam melakukan transaksi bank melalui internet/mobile banking" sebesar 3,9182 yang mana artinya bahwa responden memiliki kecenderungan untuk setuju pada pernyataan ini dibandingkan dengan pernyataan lainnya.

\section{Tabel 3.}

Deskripsi Variabel Fasilitas Lembaga Syariah

\begin{tabular}{|c|c|c|c|c|c|c|c|c|}
\hline \multirow{2}{*}{ NO } & \multirow{2}{*}{ PERNYATAAN } & \multicolumn{5}{|c|}{ JUMLAH JAWABAN } & \multirow{2}{*}{ MEAN } & \multirow{2}{*}{$\begin{array}{l}\text { STANDAR } \\
\text { DEVIASI }\end{array}$} \\
\hline & & 1 & 2 & 3 & 4 & 5 & & \\
\hline 1 & $\begin{array}{l}\text { Cabang bank syariah } \\
\text { tersebar merata di Surabaya } \\
\text { dan akses mudah dijangkau. }\end{array}$ & 3 & 5 & 28 & 47 & 27 & 3.8182 & 0.94996 \\
\hline 2 & $\begin{array}{l}\text { Nasabah dapat melakukan } \\
\text { transaksi melalui ATM bank } \\
\text { syariah yang ada di } \\
\text { Surabaya } \\
\end{array}$ & 2 & 4 & 37 & 48 & 19 & 3.7091 & 0.86040 \\
\hline 3 & $\begin{array}{l}\text { Bank syariah dalam akad } \\
\text { wadiah (tabungan) tidak } \\
\text { membebani biaya } \\
\text { administrasi } \\
\end{array}$ & 3 & 2 & 41 & 45 & 19 & 3.6818 & 0.87715 \\
\hline 4 & $\begin{array}{l}\text { Nasabah mendapat } \\
\text { kemudahan dalam } \\
\text { melakukan transaksi bank } \\
\text { melalui internet/mobile } \\
\text { banking } \\
\end{array}$ & 0 & 2 & 29 & 55 & 24 & 3.9182 & 0.74356 \\
\hline \multicolumn{6}{|c|}{ Total } & & 3.782 & \\
\hline
\end{tabular}

Dari hasil pengumpulan data kuesioner pada Tabel 4, diketahui bahwa nilai rata-rata pada variabel $Y$ (Minat Menabung) adalah 3,720 yang memiliki arti bahwa responden setuju dengan indikator pada variabel Minat Menabung. Perolehan nilai standar deviasi tertinggi ada pada pertanyaan kedua yaitu "Saya akan merekomendasikan bank syariah kepada orang lain" sebesar 0.97337 yang berarti jawaban responden lebih beragam, sedangkan nilai standar deviasi terendah pada pada pernyataan keempat yaitu " Saya akan tetap loyal (setia) menggunakan bank syariah" sebesar 0.92306 yang artinya jawaban responden cenderung lebih konsisten. Sedangkan perolehan nilai mean tertinggi ada pada pertanyaan pertama yaitu "Saya akan menggunakan produk layanan bank syariah secara terusmenerus" sebesar 3,9000 yang mana artinya bahwa responden memiliki kecenderungan untuk setuju pada pernyataan ini dibandingkan dengan pernyataan lainnya.

Tabel 4.

\section{Deskripsi Variabel Minat Menabung}

\begin{tabular}{|c|l|c|c|c|c|c|c|c|c|}
\hline \multicolumn{1}{|c|}{ Tabel 4.12 Deskripsi variabel Minat Menabung } \\
\cline { 2 - 8 } NO & \multicolumn{1}{|c|}{ PERNYATAAN } & 1 & 2 & 3 & 4 & 5 & MEAN & $\begin{array}{c}\text { STANDAR } \\
\text { DEVIASI }\end{array}$ \\
\hline 1 & $\begin{array}{l}\text { Saya akan menggunakan } \\
\text { produk layanan bank syariah } \\
\text { secara terus-menerus. }\end{array}$ & 2 & 9 & 16 & 54 & 29 & 3.9000 & 0.94772 \\
\hline 2 & $\begin{array}{l}\text { Saya akan } \\
\text { merekomendasikan bank } \\
\text { svariah kepada orang lain. }\end{array}$ & 4 & 8 & 40 & 40 & 18 & 3.5455 & $\mathbf{0 . 9 7 3 3 7}$ \\
\hline 3 & $\begin{array}{l}\text { Saya tidak akan } \\
\text { menggunakan bank } \\
\text { konvensional. }\end{array}$ & 1 & 11 & 30 & 47 & 21 & 3.6909 & 0.92613 \\
\hline 4 & $\begin{array}{l}\text { Saya akan tetap loyal (setia) } \\
\text { menggunakan bank svariah. }\end{array}$ & 2 & 5 & 37 & 41 & 25 & 3.7455 & 0.92306 \\
\hline \multicolumn{7}{|c|}{ Total } \\
\hline Sumber : Data diolah SPSS
\end{tabular}

Uji Validitas

Tabel 5.

\section{Hasil Uji Validitas X1}

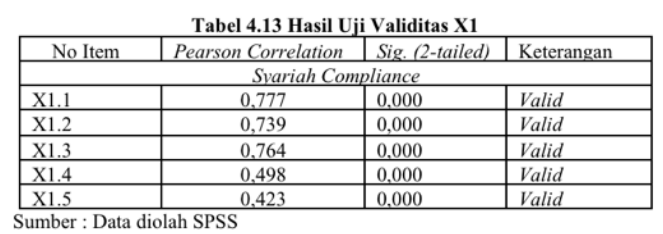

Menurut Tabel 5, seluruh variabel yang digunakan dalam penelitian dari variabel Syariah Compliance ini dengan 5 
Priambodo, et al/Jurnal Ekonomi Syariah Teori dan Terapan Vol. 6 No. 10 Oktober 2019: 2062-2076; PENGARUH BANK SYARIAH YANG DIKELOLA BERDASARKAN PRINSIP SYARIAH SERTA FITUR DAN FASILITAS PRODUK PERBANKAN SYARIAH TERHADAP MINAT MENABUNG MASYARAKAT DI SURABAYA

pertanyaan memiliki memiliki nilai signifikansi <0,05, maka dapat dinyatakan bahwa 5 pertanyaan tersebut valid.

\section{Tabel 6.}

\section{Hasil Uji Validitas X2}

Tabel 4.14 Hasil Uji Validitas X2
\begin{tabular}{|l|c|l|l|}
\hline No Item & Pearson Correlation & Sig. (2-tailed) & Keterangan \\
\hline \multicolumn{5}{|c|}{ Fasilitas Lembaga Syariah } \\
\hline X2.1 & 0,828 & 0,000 & Valid \\
\hline X2.2 & 0,884 & 0,000 & Valid \\
\hline X2.3 & 0,865 & 0,000 & Valid \\
\hline X2.4 & 0,437 & 0,000 & Valid \\
\hline
\end{tabular}
Sumber : Data diolah SPSS

Menurut Tabel 6, seluruh variabel yang digunakan dalam penelitian dari variabel Fasilitas Lembaga Syariah ini dengan 4 pertanyaan memiliki memiliki nilai signifikansi $<0,05$, maka dapat dinyatakan bahwa 4 pertanyaan tersebut valid.

Tabel 7.

\section{Hasil Uji Validitas $Y$}

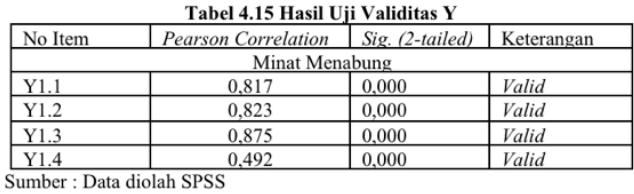

Menurut Tabel 7, seluruh variabel yang digunakan dalam penelitian dari variabel Minat Menabung ini dengan 4 pertanyaan memiliki memiliki nilai signifikansi <0,05, maka dapat dinyatakan bahwa 4 pertanyaan tersebut valid.

\section{Uji Realibilitas}

Hasil uji reliabilitas yang ditunjukkan pada Tabel 8 menunjukkan nilai Cronbach's Alpha variabel Syariah Compliance sebesar 0,646, variabel Fasilitas Lembaga Syariah sebesar 0,762 dan variabel Minat Menabung sebesar 0,746. Ketiga variabel memiliki nilai Cronbach's Alpha $>0,6$, maka ketiga variabel dalam penelitian ini dinyatakan reliabel.

Tabel 8.

\section{Hasil Uji Reliabilitas}

Tabel 4.16 Hasil Uji Reliabilitas
\begin{tabular}{|l|l|l|}
\hline No Item & Cronbach's Alpha & Keterangan \\
\hline Syariah Compliance & 0,646 & Reliable \\
\hline Fasilitas Lembaga Syariah & 0,762 & Reliable \\
\hline Minat Menabung & 0,746 & Reliable \\
\hline
\end{tabular} Sumber : Data diolah SPSS

Uji Asumsi Klasik

Berdasarkan titik-titik plotting yang terdapat pada gambar selalu mengikuti garis diagonalnya dan tidak menyebar pada bagian ujung atas maupun bawah. Oleh karena itu sebagai dasar pengambilan keputusan dalam uji normalitas dapat disimpulkan bahwa nilai residual terdistribusi normal.

Berdasarkan pengujian multikeonaritas diketahui bahwa nilai VIF variabel Syariah Compliance dan Fasilitas Lembaga Syariah sebesar 1.201. Keseluruhan nilai VIF tiap variabel adalah $<10$ yang sesuai dengan ketentuan, sedangkan nilai tolerance variabel Syariah Compliance dan Fasilitas Lembaga Syariah sebesar 0.833. Keseluruhan nilai tolerance tiap variabel adalah $>0,1$ maka dapat disimpulkan bahwa diantara variabel bebas tidak terjadi saling berhubungan atau tidak terjadi multikolinearitas.

Berdasarkan pengujian linier, diketahui bahwa nilai sig. yang dihasilkan variabel Syariah Compliance sebesar 0,000 , nilai signifikansi sesuai dengan ketentuan yatu lebih kecil dari 0,05. Dengan demikian dapat disimpulkan 
Priambodo, et al/Jurnal Ekonomi Syariah Teori dan Terapan Vol. 6 No. 10 Oktober 2019: 2062-2076; PENGARUH BANK SYARIAH YANG DIKELOLA BERDASARKAN PRINSIP SYARIAH SERTA FITUR DAN FASILITAS PRODUK PERBANKAN SYARIAH TERHADAP MINAT MENABUNG MASYARAKAT DI SURABAYA

bahwa terdapat hubungan yang linier antara variabel Syariah Compliance dan minat menabung.

Berdasarkan pengujian heterokedastisitas, titik-titik data menyebar di atas dan di bawah titik 0 . Selain itu titiktitik tersebut tidak hanya mengumpul di satu tempat di area atas maupun bawah, serta penyebaran titik tidak berpola membentuk gelombang, melebar, maupun pola lainnya. Dengan demikian dapat disimpulkan bahwa tidak terjadi heterokedastisitas pada model regresi penelitian ini.

Berdasarkan pengujian auto korelasi, diperoleh nilai Durbin Watson (dw) sebesar 1,918. Sedangkan nilai dU pada Tabel Durbin Watson adalah 1,7262, sehingga didapatkan persamaan yaitu $1,7262<1,918<2,2738$, yang mana persamaan tersebut sudah sesuai dengan ketentuan sehingga dapat disimpulkan bahwa tidak terjadi autokorelasi.

Berdasarkan hasil pengujian analisis regresi linear berganda, maka persamaan regresi berganda yang diperoleh adalah sebagai berikut:

$Y=0,079+0,800 \times 1+0,193 \times 2$

Berdasarkan persamaan regresi di atas, dapat diketahui bahwa koefisien regresi variabel Syariah Compliance adalah sebesar 0,800 dan arah hubungannya adalah positif, maka dapat ditarik kesimpulan bahwa jika variabel Syariah Compliance bertambah akan membuat Minat Menabung meningkat. Koefisien regresi variabel Fasilitas
Lembaga Syariah memiliki nilai sebesar 0,193 dan arah hubungannya adalah positif, maka dapat ditarik kesimpulan bahwa jika variabel Fasilitas Lembaga Syariah bertambah akan membuat Minat Menabung meningkat.

Berdasarkan hasil uji $F$ menunjukkan nilai sig. sebesar 0.000 yang mana sesuai dengan ketentuan yaitu nilai signifikansi $<0.05$, maka bisa disimpulkan bahwa keseluruhan variabel bebas dalam penelitian ini secara signifikan secara bersama terhadap variabel Minat Menabung.

Berdasarkan hasil uji † menunjukkan nilai sig. pada variabel Syariah Compliance sebesar 0,000 maka bisa disimpulkan bahwa variabel Syariah Compliance berpengaruh secara signifikan secara parsial terhadap variabel Minat Menabung. Pada variabel Fasilitas Lembaga Syariah terlihat nilai sig. pada variabel Fasilitas Lembaga Syariah adalah 0,011 yang mana sesuai dengan ketentuan nilai signifikansi <0.05, maka dapat disimpulkan bahwa variabel Fasilitas Lembaga Syariah berpengaruh secara parsial terhadap variabel Minat Menabung.

\section{Pembahasan}

\section{Pengaruh Syariah Compliance terhadap} Minat Menabung

Berdasarkan hasil uji † pada sub bab uji t, diketahui bahwa variabel Syariah Compliance berpengaruh terhadap variabel minat menabung. Hasil uji $\dagger$ menunjukkan nilai sig. pada variabel 
Priambodo, et al/Jurnal Ekonomi Syariah Teori dan Terapan Vol. 6 No. 10 Oktober 2019: 2062-2076; PENGARUH BANK SYARIAH YANG DIKELOLA BERDASARKAN PRINSIP SYARIAH SERTA FITUR DAN FASILITAS PRODUK PERBANKAN SYARIAH TERHADAP MINAT MENABUNG MASYARAKAT DI SURABAYA

Syariah Compliance sebesar 0.000 yang mana sesuai dengan ketentuan yaitu nilai signifikansi $<0.05$, maka bisa disimpulkan bahwa variabel Syariah Compliance berpengaruh secara signifikan secara parsial terhadap variabel minat menabung. Nilai $t$ hitung yang positif menunjukkan bahwa variabel syariah compliance mempunyai pengaruh searah terhadap variabel minat menabung.

Dalam penelitian ini, indikator dari pertanyaan yang mendapatkan nilai jawaban (mean) paling tinggi adalah pertanyaan pertama yaitu "Bank syariah tidak memberikan janji nominal tetap imbalan/pendapatan masa depan yang akan didapat nasabah (riba)", yang mana menurut responden berarti responden sudah merasa bahwa lembaga perbankan syariah di Surabaya sudah menerapkan kepatuhan syariah dengan sesuai aturan yang diajarkan oleh Agama Islam melalui Al Qur'an maupun Hadist. Penemuan ini membuktikan bahwa penelitian yang dilakukan oleh Andespa (2016) serta Gampito dan Afridawati (2017) yang mendapatkan hasil penelitian bahwa variabel syariah compliance memiliki peran penting dalam dunia lembaga perbankan syariah.

Syariah compliance memiliki pengaruh terhadap minat menabung, sehingga dapat dikatakan bahwa setiap indikator yang digunakan pada variabel syariah compliance pada penelitian ini dapat menjadi pemicu terciptanya minat dalam konsumen untuk menabung di lembaga perbankan syariah.

\section{Pengaruh Fasilitas Lembaga Syariah} terhadap Minat Menabung

Berdasarkan hasil uji † pada sub bab uji t, diketahui bahwa variabel Fasilitas Lembaga Syariah berpengaruh terhadap variabel minat menabung. Hasil uji t menunjukkan nilai sig. pada variabel Fasilitas Lembaga Syariah sebesar 0.011 yang mana sesuai dengan ketentuan yaitu nilai signifikansi <0.05, maka bisa disimpulkan bahwa variabel Fasilitas Lembaga Syariah berpengaruh secara signifikan secara parsial terhadap variabel minat menabung. Nilai $t$ hitung yang positif menunjukkan bahwa variabel Fasilitas Lembaga Syariah mempunyai pengaruh searah terhadap variabel minat menabung.

Fasilitas Lembaga Syariah memiliki pengaruh terhadap minat menabung, sehingga dapat dikatakan bahwa setiap indikator yang digunakan pada variabel Fasilitas Lembaga Syariah pada penelitian ini dapat menjadi pemicu terciptanya minat dalam konsumen untuk menabung di lembaga perbankan syariah.

\section{v. SIMPULAN}

Berdasarkan pada hasil analisa data statistik dan deskriptif, dapat disimpulkan bahwa:

1. Variabel Kepatuhan pengelolaan bank syariah berdasarkan Shariah Compliance berpegaruh terhadap minat masyarakat surabaya menabung di Lembaga perbankan 
Priambodo, et al/Jurnal Ekonomi Syariah Teori dan Terapan Vol. 6 No. 10 Oktober 2019: 2062-2076; PENGARUH BANK SYARIAH YANG DIKELOLA BERDASARKAN PRINSIP SYARIAH SERTA FITUR DAN FASILITAS PRODUK PERBANKAN SYARIAH TERHADAP MINAT MENABUNG MASYARAKAT DI SURABAYA

syariah. Sehingga hipotesis ketiga $(\mathrm{H} 1)$

diterima karena hasil yang didapatkan sesuai dengan hipotesis.

2. Variabel Fitur dan fasilitas produk lembaga perbankan syariah berpengaruh terhadap minat masyarakat Surabaya menabung di lembaga perbankan syariah. Sehingga hipotesis kedua (H2) diterima karena hasil yang didapatkan sesuai dengan hipotesis.

3. Variabel Kepatuhan pengelolaan bank syariah berdasarkan Shariah Compliance serta fitur dan fasilitas produk lembaga perbankan syariah berpengaruh terhadap minat masyarakat Surabaya menabung di lembaga perbankan Syariah. Sehingga hipotesis ketiga (H3) diterima karena hasil yang didapatkan sesuai dengan hipotesis.

\section{DAFTAR PUSTAKA}

Andespa, Roni. 2016. Strategi Pelayanan Bank Konvensional dan Syariah: Prioritas Fisik dan Empati. Jurnal Lembaga Keuangan dan Perbankan, Vol. 1 No.2.
Ghozali, I. 2016. Aplikasi Analisis Multivariete Dengan Program IBM SPSS 23 (Edisi 8). Cetakan ke VIII. Semarang : Badan Penerbit Universitas Diponegoro

Mulazid, A.S. 2016. Pelaksanaan Sharia Compliance pada Bank Syariah (Studi Kasus pada Bank Syariah Mandiri, Jakarta). Madania, Vol. 20, No. 1

Sugiyono. 2017. Metode Penelitian Kuantitatif, Kualitatif, dan R\&D. Bandung: Alfabeta, CV

Supriyono, J., Fathoni, A., Hasionaln, L. (2016). Analisis Rencana Strategi, Pengembangan Pasar, dan Kualitas Desain, terhadap Volume Penjualan pada Jamu Ratu Cantik SMK Negeri 6 Tangerang. Journal of Management. Vol. 2 No. 2

Suryani., Hendryadi. 2015. Metode Riset Kuantitatif Teori dan Aplikasi pada Penelitian Bidang Manajemen dan Ekonomi Islam. Jakarta: Prenada Media Group

Widarjono, A. 2014. Analisis Statistika Multivariat Terapan. Yogyakarta: $\begin{array}{lll}\text { UPP } & \text { STIM }\end{array}$ 